\section{Marco Polo of Australian neurology}

\author{
Matthew C Kiernan, ${ }^{1}$ Peter J Goadsby, ${ }^{\oplus 2}$ David Burke ${ }^{3}$
}

\section{The neurologist who put migraine on the map, with more than half a century of citation classics}

This month's issue of the journal contains a manuscript from Professor James Lance, ${ }^{1}$ the final contribution to a partnership with the Journal of Neurology, Neurosurgery and Psychiatry (JNNP) that dates back over some 60 years of publications. ${ }^{2-21}$ Not only a fine researcher, Lance was an expert clinician and teacher, a true gentleman of neurology.

The body of publications by Lance published in this journal mirrors his development as an academic neurologist, a career path that before Lance, had not been traversed in Australia. Lance started his mission as a postgraduate doctoral student in the fledgling brain research unit at the University of Sydney, with a particular focus on neurophysiology, then an emerging technology with as-yet unrealised potential applications to human disease. Lance's initial studies focused on the pyramidal tract, and then on human movement and movement disorders, particularly relevant to his current publication in JNNP that postulates a contribution of myoclonus to the process of falls in the elderly.

After completing MD by research, Lance moved to London, working at the Hammersmith Hospital and then the National Hospital for Neurology and Neurosurgery, Queen Square. During this period in London, Lance encountered Edward Arnold (EA) Carmichael, who had previously served as Editorin-Chief of JNNP (1938-1948, having taken over from Kinnier Wilson). ${ }^{22}$ The friendship with Carmichael led in turn to a lifelong association for Lance with JNNP. Carmichael's guiding philosophy was that the best way to study neurological disease was to study human physiology, a principle that Lance was keen to adopt for his own career. Carmichael's contributions in this regard were later

'Department of Neurology, Royal Prince Alfred Hospital, Brain and Mind Centre, University of Sydney, Sydney, New South Wales, Australia

'Headache Group, King's College London, London, UK ${ }^{3}$ Department of Neurology, Royal Prince Alfred Hospital and University of Sydney, Sydney, New South Wales, Australia

Correspondence to Professor Matthew C Kiernan, Bushell Professor of Neurology, Brain and Mind Centre, University of Sydney, Mallet Street, Sydney, NSW 2040, Australia; matthew.kiernan@sydney.edu.au

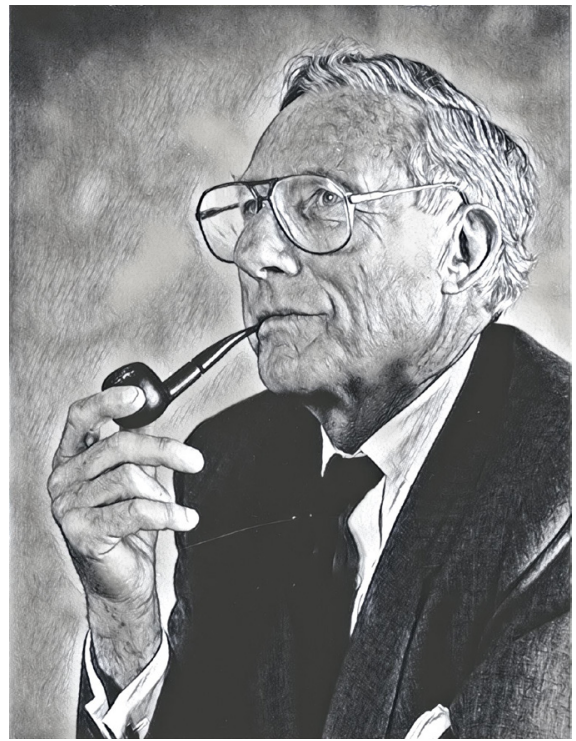

Figure 1 Professor James Waldo Lance AO CBE 29 October 1926-20 February 2019.

recognised through the establishment of the Carmichael Memorial Lecture, first delivered by Pat Merton with the title Neurophysiology on man. ${ }^{23}$

On return to Sydney, Lance became Superintendent of Northcott Neurological Centre, where he developed a lifelong interest in headache. With skills acquired at Queen Square, Lance analysed the case histories of 500 patients suffering from migraine. This research lead to his first major opus in JNNP, published in 1960, a paper that has become a citation classic.

There followed a further period of international experience, this time with Raymond D Adams at the neurology department, Massachusetts General Hospital. During this attachment, Lance and Adams described the development of post-hypoxic myoclonus, now known as the Lance-Adams syndrome and, with Robert S Schwab, he defined the action tremor of Parkinson's disease. Lance then returned to Australia to establish the country's first academic department of neurology at the Prince Henry and Prince of Wales Hospitals in Sydney, and was appointed to the first Chair of Neurology in Australia, at the University of New South Wales in 1975.
While developing concepts about motor control, in 1965, Lance demonstrated that reflex irradiation in healthy subjects and patients with spasticity was not due to intraspinal projections of group Ia afferents from the percussed muscle, but was due to the percussion spreading in bone to excite spindles in these muscles, thus setting up multiple homonymous reflex contractions. ${ }^{13} 19$ Having shown that the percussion set up a vibration that spread through the limb, he then applied a vibrating tool to his own quadriceps in an attempt to mimic the spread of vibration produced by percussion. To his amazement, he found that this produced a slow tonic contraction of the vibrated muscle. At the same time, the vibration suppressed the tendon jerk (and the $\mathrm{H}$ reflex) of the vibrated muscle, ${ }^{18}$ a phenomenon that he and his team demonstrated was a presynaptic phenomenon, now attributed to post-activation depression of transmitter release at the Ia-motoneuron synapse. With this tool, he and his students then documented the descending pathways that controlled this tonic contraction (tonic vibration reflex), ${ }^{24}$ and this formed the basis of concepts about muscle tone, posture and the control and movement. His group then addressed muscle tone and the disturbed control of movement in spasticity, ${ }^{15-17}$ Parkinson's disease, ${ }^{14}$ athetosis and cerebral palsy, setting new benchmarks in our understanding of 'why'. This work led him to be recognised internationally as one of the pioneers of an emerging field: neurophysiology studied in humans. The Lance 1980 definition of spasticity became the internationally accepted definition and is still cited whenever its mechanisms are discussed: 'Spasticity is a motor disorder characterised by a velocity-dependent increase in tonic stretch reflexes (muscle tone) with exaggerated tendon jerks, resulting from hyperexcitability of the stretch reflex, as one component of the upper motoneuron syndrome'.

A key development in growth at the rapidly evolving campus was the establishment of a headache clinic. Linked to this clinical service, research prospered. Lance focused his attention on the physiology of migraine, which soon led to work on serotonin, and particularly its effects on blood vessels and brain pathways involved in pain. This research led to the discovery by Pat Humphrey and development by Glaxo Laboratories in London of sumatriptan, the first and still most widely prescribed of the triptans, revolutionising migraine care for decades to follow. The success of this therapy promoted Glaxo to the peak of the European Stock Exchange, and led to the establishment of the James Lance GSK 
Clinical Trials Unit as part of the department of neurology of the Prince of Wales Hospital.

Further analysis of the partnership between Lance and JNNP serves to identify a persistent interest in the development of a physiological underpinning for clinical symptoms and syndromes in neurology, from headache and its various manifestations $^{61121}$ through to blip, ${ }^{5}$ neck-tongue ${ }^{12}$ and brilliantly conceived Harlequin syndromes. ${ }^{10}$ Allied to these phenomenological studies were experimental approaches to spasticity, ${ }^{15-19}$ driven by an abiding interest in reflexes ${ }^{13} 14$ and their mechanisms. ${ }^{4}$ Lance's career emphasises the importance of a clinician's curiosity and illustrates how careful clinician-led research into the mechanisms and management of neurological disorders develop our specialty. Like a fine bottle of wine from a grand vintage, these pioneering studies only serve to improve with time, being further layered by the scientific discoveries of the present day. ${ }^{25-27}$ And down to the last drop, we acknowledge a brobdingnagian career in the clinical neurosciences-vale Jim!

Correction notice This article has been corrected since it was published. The affiliations for Matthew Kiernan and David Burke have been updated.

Funding The authors have not declared a specific grant for this research from any funding agency in the public, commercial or not-for-profit sectors.

Competing interests None declared.

Patient consent for publication Not required.

Provenance and peer review Commissioned; internally peer reviewed.

(c) Author(s) (or their employer(s)) 2019. No commercial re-use. See rights and permissions. Published by BMJ.
Check for updates

To cite Kiernan MC, Goadsby PJ, Burke D. J Neurol Neurosurg Psychiatry 2019;90:627-628.

Received 11 April 2019

Accepted 11 April 2019

Published Online First 2 May 2019

\section{Clinked}

- http://dx.doi.org/10.1136/jnnp-2018-319484

J Neurol Neurosurg Psychiatry 2019;90:627-628. doi:10.1136/jnnp-2019-320989

\section{REFERENCES}

1 Lance JW, Waller SE. Drop attacks of the elderly. J Neurol Neurosurg Psychiatry 2019;90:720-3.

2 Lance JW. Impact commentaries. Observations on 500 cases of migraine and allied vascular headache. J Neurol Neurosurg Psychiatry 2012;83:673-4.

3 Drummond P, Lance JW. Harlequin syndrome: does a Cranial autonomic neuropathy influence headache? J Neurol Neurosurg Psychiatry 2012;83.

4 Lance JW. The Babinski sign. J Neurol Neurosurg Psychiatry 2002;73:360-2.

5 Lance JW. Transient sensations of impending loss of consciousness: the "blip" syndrome. J Neurol Neurosurg Psychiatry 1996;60:437-8.

6 Lance JW. Swelling at the site of a skull defect during migraine headache. J Neurol Neurosurg Psychiatry 1995;59:641

7 Lance JW. Pupillary dilatation and arm weakness as negative ictal phenomena. J Neurol Neurosurg Psychiatry 1995;58:261-2.

8 Goadsby PJ, Lance JW. Clinicopathological correlation in a case of painful ophthalmoplegia: TolosaHunt syndrome. J Neurol Neurosurg Psychiatry 1989;52:1290-3.

9 Anthony M, Lance JW. Plasma serotonin in patients with chronic tension headaches. J Neurol Neurosurg Psychiatry 1989;52:182-4.

10 Lance JW, Drummond PD, Gandevia SC, et al. Harlequin syndrome: the sudden onset of unilateral flushing and sweating. J Neurol Neurosurg Psychiatry 1988;51:635-42.

11 Drummond PD, Lance JW. Clinical diagnosis and computer analysis of headache symptoms. J Neurol Neurosurg Psychiatry 1984;47:128-33.
12 Lance JW, Anthony M. Neck-tongue syndrome on sudden turning of the head. J Neurol Neurosurg Psychiatry 1980;43:97-101.

13 Lance JW. Mechanism of the inverted Supinator reflex. J Neurol Neurosurg Psychiatry 1977; 40:207.

14 Andrews CJ, Neilson PD, Lance JW. Comparison of stretch reflexes and shortening reactions in activated normal subjects with those in Parkinson's disease. $J$ Neurol Neurosurg Psychiatry 1973;36:329-33.

15 Burke D, Andrews CJ, Lance JW. Tonic vibration reflex in spasticity, Parkinson's disease, and normal subjects. J Neurol Neurosurg Psychiatry 1972;35:477-86.

16 Burke D, Gillies JD, Lance JW. Hamstrings stretch reflex in human spasticity. J Neurol Neurosurg Psychiatry 1971:34:231-5.

17 Burke D, Gillies JD, Lance JW. The quadriceps stretch reflex in human spasticity. J Neurol Neurosurg Psychiatry 1970;33:216-23.

18 De Gail P, Lance JW, Neilson PD. Differential effects on tonic and phasic reflex mechanisms produced by vibration of muscles in man. J Neurol Neurosurg Psychiatry 1966;29:1-11.

19 Lance JW, Gail PD, DeGail P. Spread of phasic muscle reflexes in normal and spastic subjects. J Neurol Neurosurg Psychiatry 1965;28:328-34.

20 Lance JW. Sporadic and familial varieties of tonic seizures. J Neurol Neurosurg Psychiatry 1963;26:51-9.

21 Selby G, Lance JW. Observations on 500 cases of migraine and allied vascular headache. J Neurol Neurosurg Psychiatry 1960;23:23-32.

22 Editorial. J Neurol Neurosurg Psychiatry 1981:44:859-60

23 Merton PA. The first Carmichael memorial lecture. neurophysiology on man. J Neurol Neurosurg Psychiatry 1981;44:861-70.

24 Hagbarth KE, Eklund G. The effects of muscle vibration in spasticity, rigidity, and cerebellar disorders. J Neurol Neurosurg Psychiatry 1968;31:207-13.

25 Minen MT, Begasse De Dhaem 0, Kroon Van Diest A, et al. Migraine and its psychiatric comorbidities. $J$ Neurol Neurosurg Psychiatry 2016;87:741-9.

26 Mollan SP, Davies B, Silver NC, et al. Idiopathic intracranial hypertension: consensus Guidelines on management. J Neurol Neurosurg Psychiatry 2018;89:1088-100

27 Reuter U, McClure C, Liebler E, et al. Non-invasive neuromodulation for migraine and cluster headache: a systematic review of clinical trials. J Neurol Neurosurg Psychiatry 2019. doi:10.1136/jnnp-2018-320113. [Epub ahead of print: 01 Mar 2019]. 